\title{
The effects of trichothecenes on host defense against infectious diseases
}

\author{
Yoshiko Sugita-KonISHI*, Yukiko Hara-Kudo, Fumiko KASUGA \\ and Susumu KUMAGAI \\ 小西（杉田）良子*, 工藤（原）由紀子，春日文子，熊谷 進：トリコテセンによる感 \\ 染症抵抗性低下
}

\begin{abstract}
Summary
We studied that the effect of relatively low doses of five trichothecens (deoxynivalenol (DON), diacetoxyscirpenol (DAS), T-2 toxin (T-2), fusarenon-X (FX) and nivalenol (NIV)) on the host resistance against Salmonella infection using mice. Mice given daily each trichothecene in drinking water were infected orally with Salmonella enteritidis 14 days after the commencement of exposure to trichothecenes. It was found that DON was most effective among five trichothecene derivatives in decreasing the resistance against Salmonella infection. This effect of DON was associated with the reduction of serum anti-Salmonella $1 \mathrm{gM}$ titer and delated type hypersensitivety reaction, both of which are regarded as defense mechanisms against Salmonella infection. These results suggest that dietary exposure to low doses of DON enhances the susceptibity to oral infection to Salmonella through toxic effects on cellular and humoral immunity.
\end{abstract}

Key words : trichothecenes, トリコテセン; Salmonella, サルモネラ; infectious diseases, 感染 症; host resistance, 抵抗性; survival ratio, 生存率

\section{Introduction}

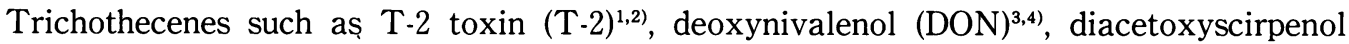
$(\mathrm{DAS})^{5,6)}$, fusarenon-X $(\mathrm{FX})^{7,8)}$ and nivalenol $(\mathrm{NlV})^{9)}$ are potent immunosuppressive mycotoxins which have contaminates frequently common agricultural products such as corn and oats. T-2 toxin $^{10-11)}$, $\mathrm{DAS}^{12-13)}$ and $\mathrm{DON}^{14-15)}$ have been demonstrated to cause necrosis of lymphoid tissue of various aminals and to suppress the mitogen-induced $T$ cell and $B$ cell blastogenesis ${ }^{16-19)}$. The immunosuppressive effects of these trichothecenes have been shown to accompany with the decrease in host resistance to infectious diseases. T-2 toxin raised mortality of chicken ${ }^{20)}$ and mice $^{21)}$ caused by salmonellosis. DON decreased survival time of mice sufferd from Listeria infection ${ }^{22}$. DAS decreased host resistance to listeriosis in mice ${ }^{23}$. However in all these findings, animals were exposed to such a high dose level as $3 \mathrm{mg} / \mathrm{kg}$ body weight of trichothecenes and the effect of lower doses of trichothecenes on host resistance against bacterial infectious diseases is still unknown.

In this study, we studied the effect of relatively low-dose exposure to trichothecenes on host

\footnotetext{
${ }^{* 1}$ Dept. Biomedical Food Research, National Institute of Infectious Diseases (1-23-1, Toyama, Shinjuku-ku, Tokyo 162-8640, Japan)

国立感染症研究所 食品衛生微生物部（广162-8640 東京都新宿区戸山 1-23-1）
} 
Table 1 Exposure dose of Trichothecene Derivatives

\begin{tabular}{cccc}
\hline \multirow{2}{*}{ group } & \multicolumn{3}{c}{ dose $(\mathrm{ppm})$} \\
\cline { 3 - 4 } & \multicolumn{1}{c}{ high dose } & medium dose & low dose \\
\hline Oxo group at C-8 & 3 & 1 & 0.2 \\
Deoxynivalenol (DON) & 6 & 1 & 0.2 \\
Nivalenol (NIV) & 3 & 1 & 0.2 \\
Fusarenon-X (FX) & & & 0.2 \\
Free or acylated hydroxy group at C-8 & 6 & 1 & 0.2 \\
T-2 toxin (T-2) & 3 & 1 & \\
Diacetpxyscirpenol (DAS) & &
\end{tabular}

resistance against salmonella infection. Drinking water containing various concentrations of five derivatives of trichothecenes were given to mice prior to inoculation of salmonella. As for DON, which was found to decrease most effectively host resistance against salmonellosis at a low dose, humoral immune and celluller mediated immune responses were also examined.

\section{Materials and methods}

DON, DAS, T-2, FX and NIV were purchased from Sigma (St. Lois, USA). Balb/c male mice purchased from the Shizuoka Laboratory Animal Center (Shizuoka, Japan) were used at 7 weeks old. In the experiment of effect of five derivatives on host resistance against salmonella infection, mice were divided into 16 groups and each group was given drinking water containing one of three different concentrations of DON, DAS, T-2, FX or NIV, or toxin-free water for 4 weeks (Table 1). On the day 14, all groups received gastric intubation of Salmonella enteritidis (S.E., strain No. E930448, phage type 4) cells suspension in PBS $\left(1 \times 10^{7}\right.$ cells $\left./ 0.2 \mathrm{ml} / \mathrm{mouse}\right)$. The survival number of mice in each group was counted during 2 weeks post-intubation. In the exeriment of the immune-defense response, mice were divided into 2 groups, a test group was given freshly drinking water containing $2 \mathrm{ppm} \mathrm{DON}$ and a control group was toxin-free water for 3 weeks. Both the groups received intubation of S. E. cells suspension in PBS $\left(6 \times 10^{5}\right.$ cells $/ 0.2$ $\mathrm{ml} /$ mouse) on the day 14 . Serum was collected on day 3,5 , and 7 after intubation.

The delayed type hypersensitivity reaction (DTH) was estimated by measuring foodpad swelling. Five days after intubation, $25 \mu \mathrm{l}$ of the formalin-treated S. E. suspension in PBS and $25 \mu \mathrm{l}$ PBS alone as control in the left and right, respectively, were injected. Titer of antiSalmonella lgM antibodies in the serum and footpad thickness were measured by as described previously ${ }^{24)}$.

\section{Results and discussion}

It has been reported that mice refuse drinking or eating when trichothecenes are added in water or feed ${ }^{25}$, respectively. As mice refused drinking water containing DON, FX and DAS at doses higher than $3 \mathrm{ppm}$ in the preliminary experiment, they were given $3 \mathrm{ppm}$ of these trichothecenes as a high dose level. The other trichothecene derivatives were given at a dose of $6 \mathrm{ppm}$ as a high dose level. Doses of $1 \mathrm{ppm}$ and $0.2 \mathrm{ppm}$ were given as medium and low doses in 
Table 2 The effect of trichothecene derivatives on Salmonella infection

\begin{tabular}{|c|c|c|c|c|}
\hline \multirow{2}{*}{ group } & \multirow{2}{*}{ name } & \multicolumn{3}{|c|}{ dose (ppm) } \\
\hline & & high dose & medium dose & low dose \\
\hline \multicolumn{5}{|c|}{ Oxo group at $\mathrm{C}-8$} \\
\hline & Deoxynivalenol (DON) & $\downarrow$ & $\downarrow$ & $\rightarrow$ \\
\hline & Nivalenol (NIV) & $\rightarrow$ & $\rightarrow$ & $\rightarrow$ \\
\hline & Fusarenon-X (FX) & $\rightarrow$ & $\rightarrow$ & $\rightarrow$ \\
\hline \multicolumn{5}{|c|}{ Free or an acylated hydroxy group at C-8 } \\
\hline & $\mathrm{T}-2$ toxin $(\mathrm{T}-2)$ & $\rightarrow$ & $\rightarrow$ & $\uparrow$ \\
\hline & Diacetpxyscirpenol (DAS) & $\rightarrow$ & $\rightarrow$ & $\downarrow$ \\
\hline
\end{tabular}

all the toxin-treated groups. The survival ratio of each group given drinking water containing various concentrations of trichothecene derivatives was compared with that of control group given toxin-free water (Table 2). DON decreased survival ratio at doses of 1 and $3 \mathrm{ppm}$. However, no change of resistance was observed in the group given NIV or FX even at a dose of 6 or 3 ppm, respectively .

A low dose level ( $0.2 \mathrm{ppm})$ of T-2 enhanced the host resistance against salmonella. Both T-2 and DAS exerted no effect at medium $(1 \mathrm{ppm})$ or high dose. The reason why the low dose modulated the resistance against salmonella is unknown. Since T-2 toxin has been observed to suppress or enhance macrophage activity depending on dose levels ${ }^{32}$, $0.2 \mathrm{ppm}$ of T-2 may have enhanced macrophage activity. These results indicate that dietary DON has the highest risk to increase the susceptibility to salmonellosis among five popular trichothecene derivatives.

In oder to elucidate what immune-defense mechanism is responsible for the increase of susceptibility to salmonella by the exposure to DON, we investigated the effects of DON on humoral and cell-mediated immune responses to salmonella infection. It is generally accepted that host defense against salmonella involves these two different types of immunity. In the humoral response, specific IgM antibodies play a major role in the primary response. Also, specific IgM antibodies were reported to be more effective than IgG antibodies in promoting the clearance of bacteria from the blood ${ }^{26)}$. In Fig. 1-(A), titer of anti-Salmonella IgM antibodies in the serum 3 days after inoculation was indicated as absorbance in ELISA. Titers of antiSalmonella IgM antibodies in the serum of the DON-treated group were significantly lower than those in the serum of the control group. Rasooly and Pestka found that the oral exposure to 25 ppm DON in feed for 4 weeks induces the hyper-elevation of total and specific serum $\operatorname{IgA}$ and the down regulation of total and specific serum $\operatorname{IgM}$ and $\operatorname{IgG}{ }^{27)}$. We found that even $2 \mathrm{ppm}$ of DON in water induced the down regulation of specific IgM. This down regulation may be one reason why DON increases the susceptibility of mice to salmonella infection.

A crucial factor in the immune mechanisms to resist the infection by intracellular parasitic bacteria is the development of a cell-mediated immune response which arrests the bacteria in the 

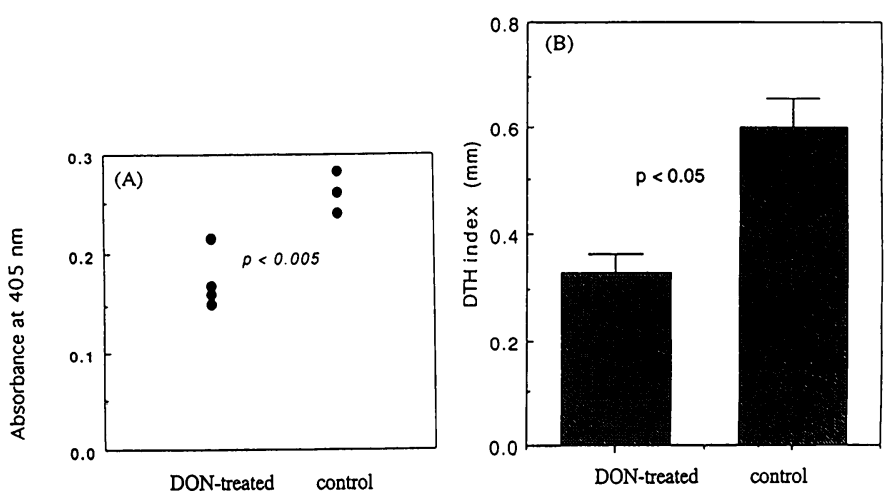

Fig. 1 Effect of DON on the production of anti-Salmonella IgM and the DTH responses following inoculation with Salmonella enteritidis.

(A) Anti-Salmonella IgM in the serum obtained on 3 days after infection was measured by ELISA. The titers were expressed as absorbances at $405 \mathrm{~nm}$. The titers of anti-Salmonella IgM in the DON treated group were significantly different from those of the oontrol group $(p<0.005)$. All groups consisted of 5 mice.

(B) DTH responses were measured via the footpad swelling response. Footpad thickness was measured $48 \mathrm{hr}$ after the injection of formalin-S. enteritidis on day 5 post-inoculation. The response of the DON treated group was significantly different from that of the oontrol group $(p<0.05)$. DTH index: the difference in the footpad thickness between the antigen-and PBS-injected mice. All groups consisted of 5 mice.

$\mathrm{RES}^{28)}$. Several approaches have been used to investigate the role of specific cell-mediated immunity against salmonella infection. In this study, the DTH reaction, which has been used as one of such approaches in mice ${ }^{29-31}$, was used as an indicator for the development of cellmediated immunity. Compared with the control group, DON-treated mice showed significantly lower $(p<0.05)$ DTH reactions (Fig. 1-(B)). The result indicates that dietary exposure to DON inhibits the development of a cell-mediated immune response, which may explain why DONtreated mice show an increase of susceptibility to salmonella infection.

Taken together, this study demonstrates that dietary exposure to DON even at such a low dose level as $120 \mu \mathrm{g} / \mathrm{kg} /$ day, which is estimated from water consumption and DON concentration in water, decreases the host resistanse against salmonella. This may be attributed to the immune toxicity of DON to suppress the production of specific IgM antibodies and to inhibit the development of a cell-mediated response against salmonella. Viewing that the most prevalent trichothecenes in Japan and the northen United States are NIV and DON, it is necessary to control DON concentrations in foods and feeds so that the amount of ingestion is suppressed below $120 \mu \mathrm{g} / \mathrm{kg} /$ day.

\section{References}

1) Saito, M., Enomoto, M. and Tatsumo, T.: Gann, 60, 599 (1969).

2) Ueno, Y.: Pure Appl. Chem., 49, 1737 (1977).

3) Arnold, D. L., McGuire, P. F., Nera. E. A., Karpinski, K. F., Bickis, M. G., Zawidzka, Z. Z., Fernie, S. and Vesonder, R. F.: Fd. Chem. Toxic., 24, 935 (1986).

4) Pestka, J. J., Tai, J. H., Witt, M. F., Dixon, D. E. and Forsell, J. H.: Fd. chem. Toxic., 25, 297 (1988). 
5) Rosenstein, Y., Lafarge-Frayssinet, C., Cohen, H., Neish, G. A and Frayssinet, C.: Immunology, 36, 111 (1979).

6) Ayral, A. M., Dubech, N., LeBars, J. and Escoula, L.: Mycopathologia, 120, 121 (1992).

7) Masuda, E., Takemoto, T., Tatsuno, T. and Obata, T.: Immunology, 47, 701 (1982).

8) Obata, T., Masuda, E., Takemoto, T. and Tatsuno, T.: "Toxigenic Fungi. Their Toxins and Health Hazard" (eds., Kurata, H. and Ueno, Y.), Amsterdam, Elsevier, p301 (1984).

9) Hinoshita, F., Suzuki, Y., Yokoyama, K., Hara, S., Yamada, A., Ogura, Y., Hashimoto, H., Tomura, S., Marumo, F. and Ueno, Y.: Nephron, 75, 469 (1997).

10) Wyatt, R. D., Hamilton, P. B. and Burmeister, H. R., Poult. Sci., 52, 1852 (1973).

11) Hoerr, F. J., Carlton, W. W. and Yagen, B. : Vet. Pathol., 18, 652 (1981).

12) LaFarge-Frayssinet, C., Lespinats, G., Lafont, P., Loisillier, F., Mousset, S., Rosenstein, Y. and Frayssinet, C. : Proc. Soc. Exp. Biol. Med., 160, 302 (1979).

13) Hoerr, F. J., Carlton, W. W. and Yagen, B. : Fd. Cosmet. Toxicol., 19, 185 (1981).

14) Cote, L. M., Beasley, V. R., Bratich, P. M. and Swanson, S. P.: J. Anim. Sci., 61, 942 (1985).

15) Coppock, R. W., Swanson, S. P., Gelberg, H. B., Koritz, G. D., Hoffman, W. E., Buck, W. B. and Vesonder, R. F.: Am. J. Vet. Res., 46, 169 (1985).

16) Osweiler, G. D., Hook, B., Mann, D. D., Buening, G. M. and Rottinghaus, G. E. : Animal Health Association, 85, 214 (1981).

17) Cooray, R.: Fd Chem. Toxicol., 22, 529 (1984).

18) Atkinson, H. A. C. and Miller, K.: Toxicol. Lett., 23, 215 (1984).

19) Forsell, J., Kately, J. R., Yoshizawa, T., and Pestka, J. J.: Appl. Environ. Microbiol., 49, 1523 (1985).

20) Boonchuvit, B., Hamilton, P. B. and Burmeister, H. R.: Poult. Sci., 54, 1693 (1975).

21) Tai, J. H., and Pestka, J. J., Fd. Chem. Toxicol., 26, 691 (1988).

22) Tryphonas, H., Iverson, F., So, Y., Nera, E. A, McGuire, P. F., O' Grady, L., Clayson, D. B. and Scott, P. M. : Toxicol. Lett., 30, 137 (1987).

23) Ziprin, R. L., and Corrier, D. E., Am. J. Vet. Res., 48, 1516 (1987).

24) Sugita-Konishi, Y., Kudo, Y., Kasuga, F. and Kumagai, S. : Mycotoxins, 44, 37 (1997).

25) Burmeister, H. R., Vesonder, R. F. and Kwolek, W. F. : Appl. Environ. Microbiol., 39, 957 (1980).

26) Saxen, H.: J. Gen. Microbiol., 130, 2277 (1984).

27) Rasooly, J., Pestka, J.: Fd. Chem. Toxic., 30, 499 (1992).

28) Collins, F. M. : Bacteriol. Rev., 38, 371 (1974).

29) Mastroeni, P., Villarreal-Pamos, B., Demarco de Hormaeche, D., Hormaeche, C. E. : Microbial Pathogen., 14, 369 (1993).

30) Killar, L. M., Eisenstein, T. K. : Infect. Immun., 52, 504 (1986).

31) Collins, F. M., Mackaness, G. B. : J. Immunol., 101, 830 (1968).

32) Vidal, D. and Mavet S. : Infect. Immun., 57, 2260 (1989). 